FIU Law Review

Volume 5 | Number 2

Article 20

Spring 2010

\title{
Two Is Company and Two Can Be a Quorum: A Reply to Professor Sanchez
}

Dennis P. Walsh

Federal Labor Relations Authority

Follow this and additional works at: https://ecollections.law.fiu.edu/lawreview

Part of the Other Law Commons

Online ISSN: 2643-7759

\section{Recommended Citation}

Dennis P. Walsh, Two Is Company and Two Can Be a Quorum: A Reply to Professor Sanchez, 5 FIU L. Rev. 739 (2010).

DOI: https://dx.doi.org/10.25148/lawrev.5.2.20

This Article is brought to you for free and open access by eCollections. It has been accepted for inclusion in FIU Law Review by an authorized editor of eCollections. For more information, please contact lisdavis@fiu.edu. 


\title{
Two Is Company and Two Can Be a Quorum: A Reply to Professor Sanchez
}

\author{
Dennis P. Walsh*
}

Professor John Sanchez has aptly laid out the arguments on both sides of the issue concerning the authority of the two-member quorum of a threemember panel to continue issuing decisions. ${ }^{1}$ He concludes, however, that the D.C. Circuit ${ }^{2}$ reached the correct conclusion based on the plain language of the statute, i.e., that there must at all times be three members on the NLRB for any group of Board members to make binding decisions. ${ }^{3}$ In this comment, I will not attempt to set forth all of the arguments on the other side. Those arguments have been thoroughly presented to the Supreme Court in the parties' briefs in the New Process case, ${ }^{4}$ and the Supreme Court has now rendered its decision on the issue. ${ }^{5}$ Instead, I will point out the primary flaws in the rationale of the D.C. Circuit that Professor Sanchez endorses, and will contend that the Supreme Court should have read the plain language of the statute to support the Board's authority to continue to issue decisions through a two-member quorum of a three-member panel to which the Board had properly delegated its powers. In addition, I will briefly address the issue of retroactivity of the Court's decision, about which Professor Sanchez speculates in his article.

First, an area of agreement. The Court correctly decided the twomember quorum issue on the basis of the plain language of Section 3(b) of the Act. The issue of whether the Court should defer to the Board's inter-

\footnotetext{
Dennis P. Walsh is currently the Deputy General Counsel at the Federal Labor Relations Authority. Mr. Walsh previously served as a Member of the National Labor Relations Board on three different occasions. Mr. Walsh was a Board Member from December 30, 2000 to December 20, 2001 under a recess appointment by President Clinton. He served again from December 17, 2002 to December 16, 2004, after being nominated by President Bush and confirmed by the Senate. He received a recess appointment to serve as a Member of the Board on January 17, 2006 and served on the Board until the Senate recessed on December 31, 2007. Mr. Walsh is currently an Adjunct Professor of Labor Law at Howard University School of Law. Mr. Walsh holds a J.D. from Cornell Law School and a B.A. from Hamilton College.

John Sanchez, Two Is Company but Is It a Quorum?, 5 FIU L. REV. 715 (2010).

Laurel Baye Healthcare of Lake Lanier v. NLRB, 564 F.3d 469 (D.C. Cir. 2009).

Sanchez, supra note 1 , at 720 .

4 New Process Steel, L.P. v. NLRB, 564 F.3d 840 (7th Cir. 2009), cert. granted, rev'd, No. 081457, slip op. (U.S. June 17, 2010) (No. 08-1457).

5 New Process Steel, No. 08-1457, slip op.
} 
pretation under the Court's Chevron decision ${ }^{6}$ was not addressed in the oral argument. ${ }^{7}$ The government, on behalf of the Board, argued that the plain meaning of the statute supports its interpretation and only argued for deference as a backup. ${ }^{8}$ In any event, it is by no means clear that Chevron deference is even applicable to this issue. As Professor Sanchez notes, two Circuit Courts - the Second and the Tenth ${ }^{9}$ - relied on Chevron deference in upholding the authority of the two-Member quorum. Each court, however, concluded that Chevron deference was applicable based on the fact that the statutory language is ambiguous, as evidenced in part by the D.C. Circuit reading it one way, while other courts read it just the opposite. ${ }^{10}$ When the Court speaks of statutory ambiguity in Chevron, however, it is not necessarily referring to semantic ambiguity. Rather, it is referring to the fact that Congress deliberately left some statutory language unclear, with the intent that the agency charged with administering the statute would have the authority to interpret and apply the language based on its accumulated experience and policy judgment. ${ }^{11}$ Congress almost certainly did not leave the language of Section 3(b) ambiguous so that the Board would have the authority to interpret whether or not it even had the authority to act in the first place. In fact, while courts have held that administrative agencies, including the Board, have the authority to determine their own "jurisdiction," the term "jurisdiction" when used in that sense refers to the extent of their substantive authority with regard to particular areas of the law, not to their power to act in the first place.

In any event, the simple fact that the words of a statute might be ambiguous does not necessarily imply that Congress has implicitly

6 Chevron U.S.A., Inc., v. Natural Res. Def. Council, 467 U.S. 837, 843 (1984) (stating that if statute is silent or ambiguous with respect to a specific issue, courts should accord deference to the agency delegated the power to interpret the statute if its interpretation is a permissible construction of the statute).

7 Justice Breyer alluded to the issue when he questioned whether the Court "should" read the statute to invalidate the two-member decisions, while it could also be read to authorize them. Transcript of Oral Argument at 15, New Process Steel, L.P. (No. 08-1457). He did not phrase his questions, however, in terms of deference to the Board's interpretation under Chevron.

8 Brief for Respondent NLRB at 32-34, New Process Steel, L.P., No. 08-1457 (U.S. Feb. 2, 2010).

9 Teamsters Local Union No. 523 v. NLRB, 590 F.3d 849, 850-52 (10th Cir. 2009), vacated No. 09-1404, slip op. (U.S. Oct. 4, 2010); Snell Island SNF LLC v. NLRB, 568 F.3d 410, 419-24 (2d Cir. 2009), vacated No. 09-328, slip op. (U.S. June 28, 2010).

10 Teamsters Local Union No. 523, 590 F.3d at 852; Snell Island, 568 F.3d at 423-24.

11 Chevron, U.S.A., Inc., 467 U.S. at 843-44.

12 See, e.g., NLRB v. City Disposal Sys., Inc., 464 U.S. 822,830 n.7 (1984). In fact, however, the Court has not definitively resolved the issue of whether it must defer to an agency's interpretation of its statutory authority to regulate a particular area of the law. Compare Miss. Power \& Light Co. v. Mississippi ex rel. Moore, 485 U.S. 354, 380-82 (1988) (Scalia, J., concurring), with id. at 386-91 (Brennan, J., dissenting). 
delegated to the administrative agency the authority to resolve that ambiguity. Especially when it comes to issues concerning the authority of the agency to act in the first place, the courts are just as capable of resolving issues of grammar and semantics as an administrative agency. And the fact that courts disagree about the meaning of particular sentences and phrases does not necessarily even mean that they could have different, plausible meanings; it could very well be that one court is correct and another is not. In this case, it could be that the First, Second, Fourth, Seventh, and Tenth Circuits have read the language of Section 3(b) correctly and the D.C. Circuit has read it incorrectly, or the other way around. Thus, the Supreme Court itself correctly resolved the conflict based on its view of the correct way to read the words of the statute.

Professor Sanchez reads the words of the statute the same as the D.C. Circuit when he concludes that "there must at all times be three members on the NLRB for any group of Board members to render binding decisions." 13 The problem with this interpretation is that it robs the term "quorum" of its true meaning. A quorum is "the minimum number of members who must be present for a deliberative assembly to legally transact business." imum number of members of the body who must be available to participate in a decision. ${ }^{15}$ The D.C. Circuit's reading, on the other hand, gives the word an entirely different meaning. Instead of setting a minimum participation level, the D.C. Circuit (and Professor Sanchez) would read the word to set a minimum membership level on the Board before any decision could be made. Thus, according to the D.C. Circuit, even if the Board has delegated its authority to a three-member panel, that panel cannot make decisions with two members if there are no longer three members sitting on the Board. This interpretation changes a quorum requirement - i.e., the number of members who must be available to participate in a decision into a membership requirement - i.e., the number of members who must be available, period.

This anomaly can be avoided if the words of the statute are simply given their ordinary and natural meaning, as the canons of statutory

13 See Laurel Baye Healthcare of Lake Lanier v. NLRB, 564 F.3d 469, 472-73 (D.C. Cir. 2009) ("A three-member Board may delegate its powers to a three-member group, and this delegee group may act with two members so long as the Board quorum requirement is, 'at all times,' satisfied.").

14 BLACK's LAW DiCTIONARY 1284 (8th ed. 2004).

15 See Assure Competitive Transp., Inc. v. United States, 629 F.2d 467, 473 (7th Cir. 1980) (stating a quorum "is a protection against totally unrepresentative action in the name of the body by an unduly small number of persons”) (quoting ROBERT's RULES OF ORDER 16 (3d ed. 1970)). 
construction require. ${ }^{16}$ The quorum provision in Section 3(b) of the Act states that "three members of the Board shall, at all times, constitute a quorum of the Board, except that two members shall constitute a quorum of any group designated pursuant to the first sentence hereof [i.e., the authority to delegate to any group of three or more members any or all of the powers which it may itself exercise]."17 The D.C. Circuit's interpretation relies heavily on the words "at all times." In that court's view, "at all times" means that the Board shall "at all times" have three members, or it cannot operate at all. This reading, however, fails to give the following phrase, "except that ..." any real meaning. If read properly, that phrase establishes an exception to the three-member quorum requirement when the Board has delegated its authority to three members. Thus, "at all times" does not truly mean that the Board must "at all times" have three sitting members, because the statute sets forth an explicit "exception" to the three-member quorum requirement.

The D.C. Circuit reads the "except" clause as simply meaning that there is a different quorum requirement for a three-member group, which does not create a true exception to the three-member quorum for the full Board. ${ }^{18}$ This is the reading, however, that results in the term "quorum" having an import that is entirely different from its accepted meaning. Under this interpretation, even if a properly constituted three-member panel has two members available to make a decision, there is no quorum unless the Board has at least three of its five slots filled. Thus, the term quorum would in effect have two different meanings: two members of the panel would have to be available to make the decision, and three members would have to be sitting on the Board before that decision could be made. By failing to understand the two-member quorum requirement as a true exception, the court (and Professor Sanchez) has created an entirely different meaning for the word "quorum."

In a very real sense, therefore, the authority of the two-member quorum of the Board should have turned on the Supreme Court's interpretation of one word, the word "except," and how that word fits into the delegation, vacancy, and quorum provisions of Section 3(b) of the Act. In order to give the word "quorum" its true meaning, in my view, the Court should have concluded that "except" means "except," i.e., that it establishes a true exception to the three-member quorum requirement when the Board has delegated its powers to a three-member group.

16 See Perrin v. United States, 444 U.S. 37, 42 (1979) (“[U]nless otherwise defined, words will be interpreted as taking their ordinary, contemporary, common meaning.").

17 National Labor Relations Act § 3(b), 29 U.S.C. § 153(b) (2006).

18 Laurel Baye Healthcare, 564 F.3d at 472. 
Professor Sanchez cites a number of policy concerns in support of his conclusion that Section 3(b) does not authorize the Board to issue decisions with a two-member quorum. These include the concern that a two-member quorum cannot consider decisions involving major policy shifts or changes in precedent, and the concern that the individual Board members who comprised the two-member quorum have suppressed their personal views and followed current precedent so that the decisions could issue. ${ }^{19}$ In essence, these concerns are based on the view that two members are simply not a sufficiently representative complement to decide cases at the National Labor Relations Board. It is Congress, however, that has determined the absolute minimum number of members that constitute "a protection against totally unrepresentative action in the name of the body by an unduly small number of persons." 20 And if the two-member quorum provision is properly read as an "exception" to the three-member quorum requirement when the Board's powers have been delegated to the three-member group, then Congress has decided the policy issue - i.e., two members are sufficient protection when such a delegation has been made.

Professor Sanchez also speculates whether the Court's decision that the Board lacked a statutory quorum should be retroactive, or prospective only. He opines that it could be given limited prospective effect, in the sense that it would apply to "all currently pending NLRB cases plus all pending appeals from NLRB rulings," but not to "all previously decided and unappealed NLRB rulings and rulings appealed, decided and not the subject of a pending cert petition." 21 However, the problem with only prospectively applying such a ruling - even if the prospective application is limited - is that, if the Board truly acted without a quorum, it had no authority to act at all. This would make any decision issued by a twomember Board a nullity. ${ }^{22}$ Any action by the Court that allowed any Board decisions to stand if they were not issued by a properly constituted quorum would fly in the face of this principle.

The issue Professor Sanchez raises is more properly considered, in my view, as a question of whether a party has waived its objection to a Board's decision by not raising the two-member quorum issue, either to the Board itself or on appeal to a circuit court. The weight of authority would seem to indicate that the issue cannot be waived. The D.C. Circuit has held that

19 Sanchez, supra note 1 , at 732.

20 Assure Competitive Transp., 629 F.2d at 473.

1 Sanchez, supra note 1, at 734.

22 See Nguyen v. United States, 539 U.S. 69, 79 (2003) (stating that decision by improperly constituted panel of Circuit Court is an action that the Court never had authority to take in first place); R.R. Yardmasters of Am. v. Harris, 721 F.2d 1332, 1338 (D.C. Cir. 1983) (stating that issue of agency's composition concerns question of agency's power to act at all). 
issues concerning the composition of an agency, and thus its power to act at all, cannot be waived by failing to raise them with the agency itself before appealing to the courts. ${ }^{23}$ And the Supreme Court held that the failure to raise the issue of the proper composition of a circuit court of appeals before the circuit court itself did not waive a party's right to raise it for the first time before the Supreme Court. ${ }^{24}$ Thus, since they are still appealable to the circuit courts, Board decisions decided by the two-member quorum remain vulnerable to challenge based on the Court's ruling that they were not properly decided. Indeed, Section 10(f) of the $\operatorname{Act}^{25}$ contains no deadline for filing a petition for review of a Board decision, so this would mean that an appeal of such decisions could be filed at any time.

Because the Court decided in New Process that the two-member quorum was not empowered to issue decisions, it has left the newly constituted Board to determine what it will do with the remaining decisions that were decided by two members. As Professor Sanchez quite aptly describes, its choice is either to ratify those decisions based on a cursory review which would leave them open to possible challenge on due process grounds - or to start at square one with every decision - which would increase the Board's backlog at a time when it has many important issues before it. Neither proposition is very attractive. ${ }^{26}$ Instead, if the Court had properly read Section 3(b) as embodying a true two-member quorum exception when the Board properly delegates its authority to a three-member panel, then today's Board would have been free to focus on important questions of labor-management policy in its current caseload.

23 See Mitchell v. Christopher, 996 F.2d 375, 378-79 (D.C. Cir. 1993); R.R. Yardmasters, 721 F.2d at $1337-39$.

$24 \quad$ Nguyen, 539 U.S. at 78-79.

25 See 29 U.S.C. $\$ 160$ (f) (2006).

26 In fact, the newly constituted Board seems to have taken an approach somewhere in between these extremes. It has asked the circuit courts to remand all of the cases that were challenged on the basis of the lack of a quorum, and it has assigned those cases for consideration by a panel consisting of Members Liebman and Schaumber, both of whom were on the two-member panel that originally decided them, and one of the new members of the Board. See NLRB Press Release, NLRB Outlines Plans for Considering 2-Member Cases in Wake of Supreme Court Ruling (July 1, 2010), available at http://www.nlrb.gov/shared_files/Press\%20Releases/2010/R-2762.pdf. 